\title{
PARTISIPASI ANGGARAN TERHADAP KINERJA MANAJERIAL DENGAN KOMITMEN ORGANISASI, MOTIVASI DAN STRUKTUR DESENTRALISASI SEBAGAI VARIABEL PEMODERASI
}

\author{
Adi Wiratno, Wahyu Ningsih dan Negina Kencono Putri \\ Universitas Jenderal Soedirman \\ Email:negina_kp@yahoo.com
}

\begin{abstract}
One way that is believed to influence the government's success in improving performance is to carry out the plan as best as possible, ie in budgeting process. Because of the nature of the budget that might have an dysfunctional budget impact then the right way to prevent is through the participation of all the budget line manager at Pemkab. Purbalingga. Factors that may increase the effect of budget participation on managerial performance improvements such as increasing organizational commitment, motivation within the manager and conditions of the delegation of authority is increasingly decentralized. This study analyze the effect of budget participation on managerial performance and the influence of organizational commitment, motivation and a decentralized structure in moderating the relationship of budget participation on managerial performance in Pemkab. Purbalingga.The samples used are 269 government manager of Pemerintah Kabupaten Purbalingga for all the regional work units. The sampling technique used is disproportionate stratified random sampling. The first hypothesis testing using simple linear regression, and for another using moderated regression analysis. Based on the analysis above all hypotheses can be concluded that the positive effect of budget participation on managerial performance. The commitment of the organization and structure of decentralized moderate the relationship between budget participation on managerial performance. While the motivation variable can not moderate the relationship of budget participation on managerial performance at SKPD in Pemkab. Purbalingga.
\end{abstract}

Key Words: Budgetary Participation, Organizational Commitment, motivation, Decentralized Structure, Managerial Performance

\begin{abstract}
Abstrak: Salah satu cara yang diyakini mempengaruhi keberhasilan pemerintah dalam meningkatkan kinerja adalah untuk melaksanakan rencana tersebut sebaik mungkin, yaitu dalam proses penganggaran. Karena sifat dari anggaran yang mungkin berdampak anggaran disfungsional maka cara yang tepat untuk mencegah adalah melalui partisipasi semua manajer garis anggaran di Pemkab. Purbalingga. Faktor-faktor yang dapat meningkatkan efek dari partisipasi anggaran pada peningkatan kinerja manajerial seperti meningkatkan komitmen organisasi, motivasi dalam manager dan kondisi pendelegasian wewenang semakin terdesentralisasi. Penelitian ini menganalisis pengaruh partisipasi anggaran terhadap kinerja manajerial dan pengaruh komitmen organisasi, motivasi dan struktur desentralisasi di moderasi hubungan partisipasi anggaran terhadap kinerja manajerial di Pemkab. sampel Purbalingga.The digunakan adalah 269 manajer Pemerintah Pemerintah Kabupaten Purbalingga untuk semua unit kerja regional. Teknik sampling yang digunakan adalah proporsional stratified random sampling. menguji hipotesis pertama menggunakan regresi linier sederhana, dan analisis regresi lain menggunakan
\end{abstract}


dimoderasi. Berdasarkan analisis di atas semua hipotesis dapat disimpulkan bahwa efek positif dari partisipasi anggaran terhadap kinerja manajerial. Komitmen organisasi dan struktur desentralisasi memoderasi hubungan antara partisipasi anggaran terhadap kinerja manajerial. Sedangkan variabel motivasi tidak dapat memoderasi hubungan partisipasi anggaran terhadap kinerja manajerial pada SKPD di Pemkab. Purbalingga.

Kata Kunci: Partisipasi Anggaran, Komitmen Organisasi, motivasi, Struktur Desentralisasi, Kinerja Manajerial

\section{PENDAHULUAN}

Salah satu faktor yang menentukan keberhasilan kinerja manajerial pada organisasi sektor publik dapat dilihat dari proses perencanaan. Karena suatu perencanaan dapat menentukan keberhasilan suatu program kegiatan. Namun, kinerja tidak dapat hanya dilihat dari input atau perencanaan program saja tetapi lebih ditekankan kepada jalannya proses, output, manfaat, dan outcome dari program kegiatan tersebut bagi kesejahteraan masyarakat. Melalui suatu pengukuran kinerja, keberhasilan manajemen dalam mengelola suatu organisasi akan lebih dilihat dari kemampuan instansi tersebut berdasarkan sumber daya yang dikelolanya untuk mencapai hasil sesuai dengan rencana yang telah dituangkan dalam perencanaan tujuan organisasi (Kristiyanti, 2012). Target dan tujuan sangat diperlukan dalam menentukan baik atau buruknya kinerja. Penetapan target dan tujuan ini dilaksanakan dalam proses penyusunan anggaran. Karena itu proses penyusunan anggaran dalam organisasi sektor publik sangatlah penting.

Hansen dan Mowen (2006) menjelaskan bahwa proses penyusunan anggaran memotivasi manajer untuk mengembangkan arah bagi organisasi, meramalkan kesulitan, dan mengembangkan kebijakan masa depan. Disisi lain, proses penyusunan anggaran merupakan kegiatan yang penting dan kompleks, karena anggaran mempunyai kemungkinan dampak fungsional dan disfungsional terhadap sikap dan perilaku anggota organisasi (Argyris, 1952), sedangkan cara untuk mencegah terjadinya dampak disfungsional anggaran, bawahan harus diberi kesempatan untuk berpartisipasi dalam proses penyusunan anggaran (Milani, 1975).

Berdasarkan penelitian-penelitian yang terdahulu hasil yang diperoleh dalam menganalisis pengaruh partisipasi anggaran terhadap kinerja manajerial masih banyak mengalami pertentangan. Hasil penelitian yang dilakukan oleh Noor dan Othman (2012), Nurhalimah, et al. (2013) dan Hashim, et al. (2014) menemukan adanya pengaruh positif antara partisipasi dalam proses penyusunan anggaran terhadap kinerja manajerial. Namun pernyataan tersebut tidak didukung oleh hasil penelitian yang dilakukan oleh Sutrisna (2011), Syahputra (2014), Rachman (2014). Hasil penelitian Sutrisna (2011) dan Syahputra (2014) menunjukan hasil yang tidak signifikan dalam hubungan antara partisipasi anggaran terhadap kinerja manajerial. Sedangkan hasil penelitian Rachman (2014) justru menunjukkan bahwa partisipasi anggaran memiliki pengaruh yang negatif terhadap kinerja.

Terkait dengan pertentangan hasil tersebut sesuai pendapat Shields dan Shields (1998) yang mempercayai bahwa dengan membandingkan faktor apa saja yang mempengaruhi partisipasi anggaran akan menghasilkan kontribusi yang besar terhadap penelitian akan partisipasi anggaran. Dimana semakin besar partisipasi anggaran akan semakin meningkatkan kinerja yang ada. Sehingga perlu dilakukan rekonsiliasi melalui 
pendekatan kontijensi dan upaya untuk menganalisis faktor-faktor kondisional yang memungkinkan dapat memperkuat hubungan partisipasi anggaran terhadap kinerja manajerial pada masing-masing organisasi. Faktor kontujensi yang akan digunakan adalah komitmen organisasi, motivasi dan struktur desentralisasi yang berperan sebagai variabel moderating. Berdasarkan permasalah diatas maka penelitian ini bertujuan untuk menganalisis pengaruh partisipasi anggaran terhadap kinerja manajerial, menganalisis pengaruh komitmen organisasi, motivasi dan struktur desentralisasi dalam memoderasi partisipasi anggaran terhadap kinerja manajerial.

\section{KAJIAN TEORI}

Teori penetapan tujuan (goal setting theory) yang dikembangkan oleh Locke (1968) menjelaskan hubungan antara tujuan yang ditetapkan dengan prestasi kerja (kinerja). Dari pendapat para ahli diatas dapat dikatakan bahwa goal setting adalah penetapan target berorientasi hasil. Dalam organisasi sektor publik, pemerintah berupaya untuk mencapai tujuan pencapaian kinerja yang optimal dengan cara melibatkan manajer tingkat bawah dan menengah dalam penyusunan anggaran sebagai alat yang diyakini akan meningkatkan pencapaian tujuan yang telah ditetapkan.

Hubungan Partisipasi Anggaran dan Kinerja Manajerial. Penyusunan anggaran secara partisipatif diharapkan dapat meningkatkan kinerja manajer, yaitu ketika suatu tujuan dirancang dan secara partisipasi disetujui maka karyawan akan menginternalisasikan tujuan yang ditetapkan dan memiliki rasa tanggung jawab pribadi untuk mencapainya, karena mereka ikut terlibat dalam penyusunan anggaran (Milani, 1975). Partisipasi anggaran membutuhkan keikutsertaan lebih banyak manajer dalam proses penyusunannya. Tidak hanya manajer tingkat atas, tetapi juga manajer tingkat menengah dan manajer tingkat bawah. Dengan adanya keterlibatan tersebut, mereka akan merasa lebih dihargai dan merasa bahwa ide-idenya dibutuhkan oleh organisasi (Ferdiani, 2012). Hal ini sesuai dengan Teori Maslow dan Teori Herzberg yang menyatakan bahwa individu memiliki kebutuhan akan aktualisasi diri. Dengan adanya partisipasi dalam penyusunan anggaran, kebutuhan tersebut dapat terpenuhi melalui penghargaan terhadap ide-ide yang dikemukakan oleh manajer.

Berdasarkan teori Goal-Setting, partisipasi akan meningkatkan komitmen manajer subordinat dalam pencapaian target anggaran (Chong dan Chong, 2002). Kesempatan untuk terlibat dan mempengaruhi dalam penyusunan anggaran akan meningkatkan kepercayaan diri dari para manajer level menengah, kontrol perasaan dan keterlibatan ego mereka dalam berorganisasi. Brownell (1982) mengatakan bahwa partisipasi dalam penyusunan anggaran merupakan proses dimana individu, yang kinerjanya dievaluasi dan memperoleh penghargaan berdasarkan pencapaian target anggaran, terlibat dan mempunyai pengaruh dalam penyusunan target anggaran. Penelitian sebelumnya yang menyatakan adanya pengaruh positif partisipasi dalam penyusunan anggaran terhadap kinerja manajerial ini telah dilakukan oleh Milani (1975), Brownell (1982), dan Brownell dan Mclnnes (1986). Pendapat yang menyatakan partisipasi anggaran akan meningkatkan kinerja juga didukung oleh hasil penelitian Noor dan Othman (2012), Nurhalimah, et al. (2013) dan Hashim, et al. (2014) Berdasarkan gambaran diatas maka dapat dirumuskan hipotesis sebagai berikut:

H1: Partisipasi anggaran berpengaruh positif terhadap kinerja manajerial. 
Menurut Govindarajan (1986), untuk merekonsiliasi temuan penelitian yang saling bertentangan, diperlukan pendekatan kontinjensi dengan mengevaluasi faktor-faktor kondisional, dalam penelitian ini misalnya kemungkinan adanya hal-hal yang dapat menyebabkan kinerja aparat menjadi lebih efektif. Teori kontijensi berargumen bahwa desain dan sistem pengendalian tergantung pada konteks organisasi dimana pengendalian tersebut dilaksanakan. Teori kontijensi menyatakan bahwa tidak ada rancangan dan penggunaan sistem pengendalian manajemen yang dapat diterapkan secara efektif untuk semua kondisi organisasi, namun sebuah sistem pengendalian tertentu hanya efektif untuk situasi atau organisasi (perusahaan) tertentu. Kesesuaian antara sistem pengendalian manajemen dan variabel kontekstual organisasi dihipotesiskan untuk menyimpulkan peningkatan kinerja organisasi dan individu yang terlibat didalamnya (Riyanto, 2001). Faktor kontijensi yang berperan sebagai variabel moderating dalam penelitian ini meliputi komitmen organisasi, motivasi dan struktur desentralisasi.

Partisipasi Anggaran, Komitmen Organisasi dan Kinerja Manajerial. Komitmen organisasi yang kuat di dalam diri individu akan menyebabkan individu berusaha keras mencapai tujuan organisasi sesuai dengan tujuan dan kepentingan organisasi serta akan memiliki pandangan positif dan lebih berusaha berbuat yang terbaik demi kepentingan organisasi (Porter, et al., 1974). Komitmen organisasi yang tinggi yang dimiliki seorang pegawai dalam melaksanakan kegiatan serta partisipasi karyawan tersebut dalam penyusunan anggaran, akan meningkatkan kinerja manajerial yang dimiliki pegawai tersebut untuk mencapai target anggaran yang telah ditetapkan. Keyakinan yang kuat yang dimiliki karyawan terhadap nilai dan tujuan yang dicapai perusahaan mempengaruhi partisipasinya yang tinggi dalam anggaran terhadap peningkatan manajerial (Coryanata, 2004). Komitmen yang tinggi menjadikan individu lebih mementingkan organisasi daripada kepentingan pribadi dan berusaha menjadikan organisasi menjadi lebih baik. Komitmen organisasi yang rendah akan membuat individu untuk berbuat untuk kepentingan pribadinya. Selain itu, komitmen organisasi dapat merupakan alat bantu psikologis dalam menjalankan organisasinya untuk pencapaian kinerja yang diharapkan (Chong \& Chong, 2002).

Hasil penelitian Putra, et al. (2014) menyatakan bahwa partisipasi dalam penyusunan anggaran mempengaruhi kinerja manajerial dengan komitmen organisasi sebagai variabel moderating. Begitu pula hasil penelitian yang dilakukan oleh Sardjito dan Muthaher (2007) yang menyatakan bahwa partisipasi anggaran akan meningkatkan kinerja manajerial para anggota organisasi jika atasan setingkat kepala dinas peduli dan perhatian terhadp komitmen para bawahan dalam berpartisipasi untuk menyusun anggaran maka tujuan sasaran anggaran yang akan dapat dicapai. Berdasarkan gambaran diatas maka dapat dirumuskan hipotesis sebagai berikut:

H2 : Komitmen organisasi memperkuat pengaruh partisipasi anggaran terhadap kinerja manajerial.

Partisipasi Anggaran, Motivasi Kerja, dan Kinerja Manajerial. Motivasi menurut Lawler, et al. (1973) merupakan derajat sampai dimana seorang individu ingin dan berusaha untuk melaksanakan suatu tugas atau pekerjaan dengan baik dan kesediaan untuk mengeluarkan tingkat upaya yang tinggi ke arah tujuan organisasi, yang dikondisikan dengan kemampuan upaya tersebut guna memenuhi suatu kebutuhan individual. Sedangkan menurut Gitosudarmo dan Sudita (2002), motivasi merupakan faktor-faktor yang ada dalam diri seseorang dalam mengarahkan perilakunya untuk memenuhi tujuan 
tertentu. Proses timbulnya motivasi seseorang merupakan gabungan dari konsep kebutuhan, dorongan, tujuan dan imbalan.

Apabila dikaitkan dengan anggaran maka dalam proses penyusunan anggaran akan lebih efektif dalam kondisi karyawan yang mempunyai motivasi tinggi, begitu pula sebaliknya (Ghozali dan Adiputra, 2002). Dengan adanya motivasi yang tinggi maka keinginan untuk berpartisipasi dalam penyusunan anggaran akan semakin besar, karena keterlibatan dalam penyusunan anggaran merupakan salah satu cara demi pencapaian tujuan dari alasan seseotang termotivasi untuk melakukan pekerjaan dengan baik.

Keterkaitan antara motivasi terhadap hubungan partisipasi anggaran dengan kinerja manajerial telah banyak diteliti oleh para peneliti terdahulu. Brownell dan McInnes (1986) dan Mia (1988) mengemukakan bahwa partisipasi penyusunan anggaran berpengaruh positif terhadap kinerja manajerial dengan motivasi kerja sebagai variabel moderating. Jadi dalam hal ini karyawan yang memiliki motivasi yang lebih baik (tinggi) akan memperbaiki kesalahan atau merasa khawatir jika kinerjanya dibawah tingkat pengharapannya (rendah). Hasil tersebut juga didukung oleh penelitian Suhartono dan Halim (2005) serta penelitian Ghozali dan Adiputra (2002). Berdasarkan hasil penelitian tersebut dapat disusun rumusan hipotesis sebagai berikut.

H3 : Motivasi memperkuat pengaruh partisipasi anggaran terhadap kinerja manajerial.

Partisipasi Anggaran, Struktur Desentralisasi, dan Kinerja Manajerial. Otonomi daerah membawa implikasi pada pelimpahan wewenang yang lebih luas kepada pemerintah daerah, sehingga proses efektivitas penggunaan anggaran sangat tergantung dengan pelimpahan wewenang yang terjadi di pemerintah daerah. Pelimpahan wewenang yang terdesentralisasi diperlukan karena dalam struktur yang terdesentralisasi para manajer/bawahan diberikan wewenang dan tanggungjawab yang lebih besar dalam pengambilan keputusan (Nor, 2007).

Terkait dengan proses penganggaran adanya desentralisasi akan membuat wewenang dan tanggung jawab atas keberhasilan proses penganggaran tersebut menjadi lebih besar. Hal tersebut akan membuat pihak terkait akan lebih melibatkan diri dan berpartisipasi dalam proses penyusunan anggaran, dan keterlibatan tersebut akan membuat mereka berusaha seoptimal mungkin dalam pencapaian tujuan organisasi. Secara lebih spesifik desentralisasi tidak saja merupakan sebuah variabel kontinjensi yang penting dalam perancangan sistem akuntansi manajemen, tetapi juga merupakan mekanisme penunjang yang seharusnya konsisten dengan maksud penyusunan struktur formal (Chenhall dan Morris, 1986).

Pentingnya desentralisasi bagi efektivitas penggunaan anggaran telah terbukti secara empiris dalam penelitian Govindarajan (1986) yang menunjukkan bahwa tingkat desentralisasi yang tinggi merupakan bentuk yang tepat untuk menghadapi peningkatan ketidakpastian sehingga menunjang pencapaian kinerja. Hasil penelitian Gul, et al., (1995) menemukan bahwa partisipasi anggaran terhadap kinerja akan berpengaruh positif dalam organisasi yang pelimpahan wewenangnya bersifat desentralisasi. dan berpengaruh negatif dalam organisasi yang pelimpahan wewenangnya bersifat sentralisasi. Hasil tersebut didukung oleh penelitian Coryanata (2004) dan Ika S, et al. (2011). Berdasarkan hasil penelitian tersebut dapat disusun rumusan hipotesis sebagai berikut.

H4 : Struktur desentralisasi memperkuat pengaruh partisipasi anggaran terhadap kinerja manajerial. 


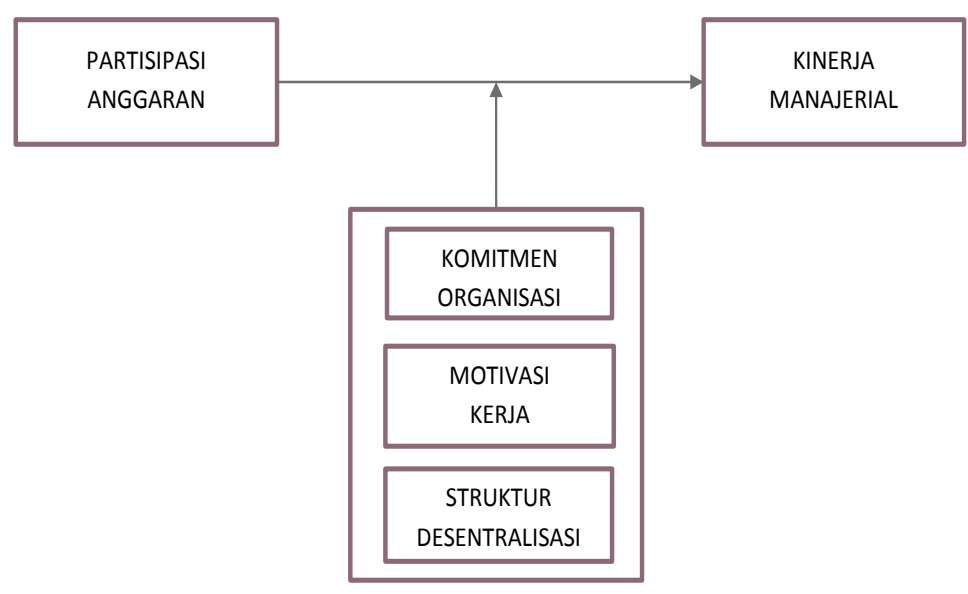

Gambar 1. Model Penelitian

\section{METODE}

Populasi dan Sampel. Populasi dalam penelitian ini adalah pejabat struktural Eselon II, III, IV dan V pada seluruh Satuan Kerja Perangkat Daerah (SKPD) yang masih aktif bertugas. Jumlah populasi penelitian sebanyak 772 pejabat struktural. Data dalam penelitian ini diperoleh dari data primer melalui metode survei. Pengambilan sampel dilakukan dengan teknikdisproportionated stratified random sampling. Penentuan jumlah sampel dengan menggunakan rumus Slovin.

Definisi Operasional Variabel. (1) Partisipasi Anggaran. Partisipasi anggaran merupakan suatu proses yang melibatkan individu secara langsung di dalamnya dan mempunyai pengaruh terhadap penyusunan tujuan anggaran yang prestasinya akan dinilai dan kemungkinan akan dihargai atas dasar pencapaian tujuan anggaran mereka (Milani, 1975). Instrumen untuk mengukur variabel partisipasi dalam penganggaran mengadopsi instrumen yang digunakan dalam penelitian Milani (1975) yang terdiri dari enam indikator. (2) Komitmen Organisasi. Komitmen organisasi adalah sikap yang ditunjukan dimana individu lebih memihak organisasi dan tujuan organisasi serta memelihara keanggotaan untuk mencapai tujuan organisasi (Mowday, et al. 1979). Variabel ini diukur dengan menggunakan instrumen yang dikembangkan oleh Mowday, et al. (1979) yang terdiri dari sembilan indikator. (3) Motivasi. Motivasi kerja merupakan derajat sampai dimana individu ingin dan berusaha untuk melaksanakan suatu pekerjaan dengan baik (Lawler, et al., 1973). Motivasi diukur dengan menggunakan dua belas item pernyataan yang menggambarkan tingkat persepsi responden terhadap bagaimana keinginan pribadi apabila mengerjakan sesuatu dengan sangat baik (faktor intrinsik) dan bentuk imbalan dan kesempatan setelah mengerjakan sesuatu dengan sangat lebih baik (faktor ekstrinsik). (4) Struktur Desentralisasi. Struktur desentralisasi dalam penelitian ini adalah derajat pelimpahan wewenang, berkaitan dengan wewenang yang diberikan oleh pimpinan kepada bawahan (Gordon dan Narayanan, 1984). Struktur desentralisasi diukur dengan menggunakan enam item pernyataan yangdiadopsi dari penelitian Gardon dan Narayana (1984) yang telah dikembangkan oleh Gul, et al. (1995). (5) Kinerja Manajerial. Menurut Mahoney, et al. (1963) kinerja (performance) adalah hasil kerja yang dapat dicapai oleh 
seseorang atau kelompok orang dalam suatu organisasi, sesuai dengan wewenang dan tanggung jawab masing-masing, dalam rangka mencapai tujuan organisasi.Kinerja manajerial diukur dengan menggunakan tujuh item pernyataan yang diadaptasi dari penelitian Mahoney, et al. (1963).

Teknik Analisis Data. Pengujian Hipotesis 1 menggunakan regresi linier sederhana sedangkan untuk Hipotesis 2-4 menggunakan moderated regression analysis. Model persamaan masing-masing hipotesis dirumuskan sebagai berikut:

1. $\mathrm{Y}=\mathrm{a}+\mathrm{b}_{1} \mathrm{X}_{1}+\mathrm{e}$

2. $Y=a+b_{1} X_{1}+b_{2} X_{2}+b_{5} X_{1} * X_{2}+e$

3. $Y=a+b_{1} X_{1}+b_{3} X_{3}+b_{6} X_{1} * X_{3}+e$

4. $\mathrm{Y}=\mathrm{a}+\mathrm{b}_{1} \mathrm{X}_{1}+\mathrm{b}_{4} \mathrm{X}_{4}+\mathrm{b}_{7} \mathrm{X}_{1} * \mathrm{X}_{4}+\mathrm{e}$

Keterangan: Y : Kinerja Manajerial pada SKPD; X1 : Partisipasi Anggaran; X2 :

Komitmen Organisasi; X3 : Motivasi Kerja; X4 : Struktur Desentralisasi; a : Konstanta; b1- b7 : Koefisien Regresi; X1*X2 : Interaksi partisipasi anggaran dengan komitmen organisasi; $\mathrm{X} 1 * \mathrm{X} 3$ : Interaksi antara partisipasi anggaran motivasi kerja; $\mathrm{X} 1 * \mathrm{X} 4$ : Interaksi partisipasi anggaran dengan struktur desentralisasi; e : error atau variabel pengganggu.

\section{HASIL DAN PEMBAHASAN}

Pengumpulan data dilakukan pada tanggal 12 Oktober - 30 Oktober 2015 yang didistribusikan langsung pada masing-masing instansi pemerintah Kabupaten Purbalingga. Perhitungan tingkat pengembalian kuesioner dapat dilihat pada tabel berikut ini:

Tabel 1. Gambaran Umum Jumlah Kuesioner

\begin{tabular}{lc}
\hline Keterangan & Jumlah \\
\hline Jumlah kuesioner disebar & 350 \\
Jumlah kuesioner kembali & 287 \\
Kuesioner yang tidak dapat digunakan & 18 \\
Kuesioner yang dapat digunakan & 269 \\
Jml kuesioner menurut rumus Slovin & 264 \\
\hline
\end{tabular}

Pada Tabel 2 disajikan kisaran-kisaran teoritis yang merupakan kisaran atas bobot jawaban yang secara teoritis didesain dalam kuesioner dan kisaran sesungguhnya yaitu nilai terendah sampai nilai tertinggi atas jawaban responden yang sesungguhnya.

Tabel 2. Tabel Statistik Deskriptif

\begin{tabular}{lccccc}
\hline & N & Minimum & Maximum & Mean & Std. Deviation \\
\hline Kinerja Manajerial & 269 & 19 & 35 & 28,25 & 2,742 \\
Partisipasi Anggaran & 269 & 11 & 30 & 23,58 & 3,125 \\
Komitmen Organisasi & 269 & 22 & 45 & 32,58 & 4,670 \\
Motivasi & 269 & 33 & 60 & 47,01 & 4,552 \\
Struktur Desentralisasi & 269 & 15 & 30 & 21,84 & 3,019 \\
Valid N (listwise) & 269 & & & & \\
\hline
\end{tabular}


Pengujian Hipotesis 1. Untuk mengetahui adanya pengaruh antara partisipasi penyusunan anggaran terhadap kinerja manajerial, digunakan uji regresi linier sederhana dengan hasil yang tercantum dalam Tabel 3.

Tabel 3. Pengaruh Partisipasi Anggaran Terhadap Kinerja Manajerial

\begin{tabular}{clr}
\hline No & \multicolumn{1}{c}{ Keterangan } & \multicolumn{1}{c}{ Nilai } \\
\hline 1 & Model Summary & \\
& Nilai R & 0,552 \\
& Nilai R Square & 0,305 \\
2 & ANOVA & \\
& Nilai F & 117,193 \\
& Sig. & 0,000 \\
3 & Coefficients & \\
& Nilai Konstanta & 16,825 \\
& Nilai b1 & 0,485 \\
& Nilai t (Partisipasi Anggaran) & 10,826 \\
& Sig. (Partisipasi Anggaran) & 0,000 \\
\hline
\end{tabular}

Berdasarkan hasil uji hipotesis 1 dapat dirumuskan persamaan regresi sebagai berikut: $\mathrm{Y}=16,825+0,485 \mathrm{X}_{1}$

Dari hasil tabel di atas juga dapat diketahui bahwa ternyata terdapat pengaruh antara partisipasi penyusunan anggaran terhadap kinerja manajerial, yang ditunjukkan dengan nilai $\mathrm{R}^{2}=0,305$ yang berarti bahwa partisipasi penyusunan anggaran menjelaskan 30,5 \% variabilitas kinerja manajerial. Nilai t hitung sebesar 10,828 lebih besar dari t tabel 1,968 dengan signifikasi sebesar 0,000 yang lebih kecil dari $\alpha=0,05$ menunjukkan adanya pengaruh positif antara partisipasi penyusunan anggaran terhadap kinerja manajerial. Sehingga dapat dikatakan bahwa semakin tingginya tingkat partisipasi dalam penyusunan anggaran akan mengakibatkan meningkatnya kinerja manajerial. Penyusunan anggaran dapat berperan sebagai perencanaan dan kriteria kinerja, dimana anggaran dapat dipakai sebagai suatu sistem pengendalian untuk mengukur kinerja manajerial. Hal ini berarti anggaran partisipatif dapat dinilai sebagai pendekatan manajerial yang dapat meningkatkan kinerja setiap manajer sebagai individual karena dengan adanya partisipasi dalam penyusunan anggaran diharapkan setiap individu mampu meningkatkan kinerjanya sesuai dengan target yang telah ditetapkan sebelumnya (Sardjito dan Muthaher, 2007).

Hasil penelitian ini sejalan dengan hasil penelitian yang telah dilakukan oleh Noor dan Othman (2014), Nurhalimah, et al. (2013) dan Hashim, et al. (2014) yang menyatakan bahwa semakin tinggi keterlibatan manajer dalam proses penyusunan anggaran maka kinerja manajerial yang mereka hasilkan akan semakin tinggi pula. Namun hasil penelitian ini tidak sejalan dengan penelitian Sutrisna (2011) dan Syahputra (2013) dimana mereka justru menemukan bahwa partisipasi anggaran tidaklah berpengaruh terhadap peningkatan kinerja manajerial.

Pengujian Hipotesis 2. Untuk mengetahui adanya pengaruh antara variabel komitmen organisasi dalam memoderasi hubungan partisipasi anggaran terhadap kinerja manajerial, 
digunakan uji interaksi atau disebut moderated regresion analysis. Berdasarkan hasil pengujian yang dilakukan diperoleh nilai yang tercantum dalam Tabel 4.

Tabel 4. Pengaruh Komitmen Organisasi dalam Memoderasi Pengaruh Partisipasi Anggaran Terhadap Kinerja Manajerial

\begin{tabular}{ccc}
\hline No & \multicolumn{1}{c}{ Keterangan } & Nilai \\
\hline 1 & Model Summary & \\
& Nilai R & 0,596 \\
& Nilai R Square & 0,355 \\
2 & ANOVA & \\
& Nilai F & 48,553 \\
& Sig. & 0,000 \\
3 & Coefficients & \\
& Nilai Konstanta & 35,528 \\
& Nilai b1 & $-0,417$ \\
& Nilai b2 & $-0,563$ \\
& Nilai b5 & 0,027 \\
& Nilai t (PA.KO) & 3,473 \\
& Sig. (PA.KO) & 0,001 \\
\hline
\end{tabular}

Persamaan yang dapat diperoleh dari hasil pengujian hipotesis ini yaitu:

$$
\mathrm{Y}=35,528-0,417 \mathrm{X}_{1}-0,563 \mathrm{X}_{2}+0,027 \mathrm{X}_{1} \mathrm{X}_{2}
$$

Dari hasil output pada Tabel 4. dinyatakan bahwa nilai uji interaksi (komitmen organisasi sebagai variabel moderating) menunjukkan nilai koefisien determinasi ( $\mathrm{R}$ Square) sebesar 0,355 berarti kinerja manajerial dapat dijelaskan oleh variabel partisipasi anggaran dan komitmen organisasi sebesar 35,5 persen. Nilai t hitung sebesar 3,473 dengan signifikasi sebesar sebesar 0,001 yang lebih kecil dari $\alpha=0,05$ berarti hipotesis 2 yang diajukan dapat diterima. Dengan demikian, hasil penelitian ini mendukung hipotesis yang menyatakan partisipasi penyusunan anggaran berpengaruh positif terhadap kinerja manajerial ketika komitmen organisasi tinggi.

Dalam hal ini komitmen organisasi berperan sebagai ikatan keterkaitan individu dengan organisasi (Mathiew dan Zajac, 1990) sehingga individu tersebut merasa memiliki organisasinya dengan demikian dapat meningkatkan kinerja manajerialnya. Partisipasi seluruh lini manajer dalam pembuatan keputusan kebijakan, memperkuat tendensi bawahan untuk mengenal organisasi, dengan demikian komitmen organisasi akan meningkat. Komitmen organisasi yang kuat akan mendorong para manajer bawahan berusaha keras mencapai tujuan organisasi (Porter et al., 1974).

Temuan penelitian ini sejalan dengan penelitian Sardjito dan Muthaher (2007), Indarto dan Ayu (2011) dan Putra, et al. (2014). Hasil penelitian mereka mengindikasikan bahwa partisipasi seluruh lini manajer dalam penyusunan anggaran lebih efektif jika keputusan-keputusan yang penting dalam organisasi lebih sering dibuat secara kelompok. Partisipasi anggaran akan meningkatkan kinerja manajerial para anggota organisasi jika atasan setingkat manajer peduli dan memperhatikan masalah komitmen organisasi dalam bekerja. Sedangkan penelitian Hidayah dan Fauziah (2010) dan Sutrisna (2011) tidak 
memperoleh hasil yang sama, dimana penelitian mereka tidak menemukan pengaruh komitmen organisasi dalam memoderasi partisipasi anggaran terhadap kinerja manajerial.

Pengujian Hipotesis 3. Untuk mengetahui adanya pengaruh antara variabel motivasi kerja dalam memoderasi hubungan partisipasi penyusunan anggaran dengan kinerja manajerial, digunakan uji regresi berganda dengan variabel moderasi. Berdasarkan hasil pengujian yang dilakukan diperoleh nilai-nilai yang tercantum dalam Tabel 5.

Tabel 5. Pengaruh Motivasi dalam Memoderasi Pengaruh Partisipasi Anggaran Terhadap Kinerja Manajerial

\begin{tabular}{clr}
\hline No & \multicolumn{1}{c}{ Keterangan } & \multicolumn{1}{c}{ Nilai } \\
\hline 1 & Model Summary & \\
& Nilai R & 0,602 \\
& Nilai R Square & 0,363 \\
2 & ANOVA & \\
& Nilai F & 50,295 \\
& Sig. & 0,000 \\
3 & Coefficients & \\
& Nilai Konstanta & 19,771 \\
& Nilai b1 & 0,053 \\
& Nilai b3 & $-0,022$ \\
& Nilai b6 & 0,007 \\
& Nilai t (PA.MOT) & 0,881 \\
& Sig. (PA.MOT) & 0,379 \\
\hline
\end{tabular}

Dari hasil Tabel 5 tersebut diturunkan model persamaan regresi linier yang terbentuk: $\mathrm{Y}=19,771+0,053 \mathrm{X}_{1}-0,022 \mathrm{X}_{3}+0,007 \mathrm{X}_{1} \mathrm{X}_{3}$

Berdasarkan Tabel 5. dapat diketahui nilai koefisien determinasi (R Square) sebesar 0,363 berarti kinerja manajerial dapat dijelaskan oleh variabel partisipasi anggaran dan motivasi kerja sebesar 36,3 persen, sedangkan sisanya yaitu 68,8 persen dijelaskan oleh variabel lain yang tidak diteliti. Nilai F sebesar 50,295 dengan signifikansi 0,000 menunjukkan model dapat dikatakan fit. Nilai t hitung sebesar 0,881 dengan signifikasi lebih besar dari $\alpha=0,05$ yaitu sebesar 0,379 sehingga hasil penelitian ini menyatakan bahwa motivasi memiliki pengaruh yang positif namun tidak signifikan atas hubungan partisipasi penyusunan anggaran terhadap kinerja manajerial. Dengan kata lain hasil penelitian ini menolak hipotesis 3 .

Hal ini mungkin dapat disebabkan karena motivasi yang ada pada diri pejabat struktural lebih banyak diarahkan pada bagaiamana manajer tersebut memperoleh hasil akhir atau imbalan yang diterima, dengan kata lain tinggi rendahnya motivasi yang ada pada diri pejabat struktural akan berbeda. Dan perbedaan tersebut dapat dipengaruhi oleh fsktor-faktor lain seperti sifat pribadi dari responden itu sendiri (Brownell, 1981). Dengan adanya sifat pribadi yang berbeda tentu akan membuat ukuran motivasi dalam proses partisipasi penyusunan anggaran tidaklah sama.

Implikasinya pada sektor publik, anggaran pada pemerintah sudah dapat mencerminkan bagaimana anggaran tersebut direalisasikan serta kegiatan-kegiatan apa 
saja yang dapat dilaksanakan, sehingga tinggi atau rendahnya motivasi tidak menjadikan partisipasi anggaran yang dilakukan oleh manajer semakin besar pengaruhnya terhadap kinerja manajerial. Atau dengan kata lain adanya motivasi diri pejabat struktural pada pemerintah kabupaten Purbalingga tidak berpengaruh signifikan dalam peningkatan hubungan partisipasi anggaran terhadap kinerja manajerial. Dari hasil tersebut dapat berarti bahwa penyusunan anggaran yang merupakan rutinitas dalam kegiatan pemerintahan akan tetap berjalan sebagaimana semestinya baik dengan adanya motivasi yang tinggi maupun rendah yang berasal dari faktor intrinsik maupun ekstrinsik diri para pejabat struktural tersebut.

Hasil penelitian ini berbeda dari penelitian yang dilakukan oleh Mia (1988) dan Brownell dan McInnes (1986) yang menujukkan bahwa motivasi secara signifikan berperan sebagai variabel moderating dalam hubungan antara partisipasi anggaran dengan kinerja. Namun hasil penelitian ini mendukung penelitian yang dilakukan oleh Riyadi (2000) dan Sutrisna (2011) menyatakan bahwa partisipasi dalam penyusunan anggaran dengan motivasi sebagai variabel moderasi tidak memiliki pengaruh signifikan dengan peningkatan kinerja. Selain itu ada kemungkinan lain yakni motivasi masing-masing individu tersebut lebih mengarah pada imbalan atau gaji maupun tunjangan yang akan mereka terima. Sedangkan pada pemerintah Kabupaten Purbalingga belum diberlakukan sistem reward and punishment yang dapat memotivasi lebih agar keterlibatan mereka dalam penyusunan anggaran akan lebih meningkatkan kinerja manajerial.

Pengujian Hipotesis 4. Untuk mengetahui adanya pengaruh antara variabel struktur desentralisasi dalam memoderasi hubungan partisipasi penyusunan anggaran dengan kinerja manajerial, digunakan uji interaksi atau disebut moderated regretion analysis. Berdasarkan hasil pengujian yang dilakukan diperoleh nilai-nilai yang tercantum dalam Tabel 6.

Tabel 6. Pengaruh Struktur Desentralisasi dalam Memoderasi Pengaruh Partisipasi Anggaran Terhadap Kinerja Manajerial

\begin{tabular}{ccr}
\hline No & \multicolumn{1}{c}{ Keterangan } & \multicolumn{1}{c}{ Nilai } \\
\hline 1 & Model Summary & \\
& Nilai R & 0,595 \\
& Nilai R Square & 0,354 \\
2 & ANOVA & \\
& Nilai F & 48,499 \\
& Sig. & 0,000 \\
3 & Coefficients & \\
& Nilai Konstanta & 21,703 \\
& Nilai b1 & 0,11 \\
& Nilai b4 & $-0,184$ \\
& Nilai b7 & 0,015 \\
& Nilai t (PA.SD) & 2,185 \\
& Sig. (PA.SD) & 0,030 \\
\hline
\end{tabular}

Dari hasil Tabel 6 tersebut diturunkan model persamaan regresi linier yang terbentuk: 


$$
\mathrm{Y}=21,703+0,110 \mathrm{X} 1-0,184 \mathrm{X} 4+0,015 \mathrm{X} 1 \mathrm{X} 4
$$

Dari hasil output pada Tabel 4.12 dapat diketahui bahwa nilai uji interaksi (struktur desentralisasi sebagai variabel moderating) menunjukkan Nilai koefisien determinasi (R Square) sebesar 0,354 berarti kinerja manajerial dapat dijelaskan oleh variabel partisipasi anggaran dan struktur desentralisasi sebesar 35,4 persen, sedangkan sisanya, yaitu 64,6 persen dijelaskan oleh variabel lain yang tidak diteliti.Nilai $\mathrm{F}$ sebesar 48,499 dengan signifikansi 0,000 menunjukkan model dapat dikatakan fit. Nilai t hitung sebesar 2,185 dengan signifikasi sebesar sebesar 0,030 yang lebih kecil dari $\alpha=0,05$ berarti hipotesis 3 yang diajukan dapat diterima. Dengan demikian, hasil penelitian ini mendukung hipotesis yang menyatakan partisipasi penyusunan anggaran berpengaruh positif terhadap kinerja manajerial ketika pelimpahan wewenang semakin terdesentralisasi.

Dengan adanya pelimpahan wewenang yang terdesentralisasi maka pejabat struktural dari tingkatan tertinggi hingga terendah akan terlibat dalam proses penyusunan anggaran, sehingga dengan keterlibatan itu akan meningkatkan rasa tanggung jawab dalam melaksanakan kegiatan manajerial dengan seoptimal mungkin. Struktur desentralisasi dapat berperan sebagai variabel moderating karena nilai $\mathrm{R}$ Square mengalami kenaikan setelah adanya interaksi. Hasil penelitian ini sejalan dengan penelitian dari Gul, et al. (1995) yang menyatakan bahwa struktur desentralisasi memoderasi hubungan partisipasi anggaran terhadap kinerja manajerial.

Hasil ini menunjukkan bahwa semakin tinggi tingkat desentralisasi yang diberikan pimpinan kepada bawahan atau manajer, maka semakin tinggi pula kinerja manajerial yang diperoleh manajer tersebut. Hal ini berarti bahwa pembagian kekuasaan yang terdesentralisasi mendorong para manajer/bawahan untuk berpartisipasi aktif dalam penyusunan anggaran. Partisipasi yang diberikan manajer dalam penyusunan anggaran akan mengakibatkan terjadinya peningkatan kinerja manajerial yang akan dicapai oleh manajer/bawahan.

Hasil penelitian ini mendukung penelitian Gul et al. (1995), Coryanata (2004) dan Ika S, et al. (2011) yang menyatakan bahwa partisipasi penyusunan anggaran terhadap kinerja manajerial akan berpengaruh positif dalam organisasi yang pelimpahan wewenangnya bersifat desentralisasi, dan akan berpengaruh negatif dalam organisasi yang pelimpahan wewenangnya sentralisasi. Sedangkan hasil penelitian Nor (2007) menemukan bahwa desentralisasi tidak mempengaruhi hubungan antara partisipasi penyusunan anggaran dengan kinerja manajerial. Begitu juga dengan penelitian Sutrisna (2011) yang menunjukkan bahwa desentralisasi tidak memengaruhi hubungan antara partisipasi anggaran dengan kinerja.

\section{PENUTUP}

Simpulan. Berdasarkan hasil analisis sebagaimana telah diuraikan sebelumnya maka dapat diambil kesimpulan sebagai berikut: (1) Partisipasi anggaran berpengaruh positif signifikan terhadap kinerja manajerial pada Pemerintah Kabupaten Purbalingga; (2) Komitmen organisasi memoderasi hubungan antara partisipasi anggaran terhadap kinerja manajerial pada SKPD; (3) Motivasi tidak dapat memoderasi hubungan antara partisipasi anggaran terhadap kinerja manajerial pada SKPD; (4) Struktur desentralisasi memoderasi hubungan antara partisipasi anggaran terhadap kinerja manajerial pada SKPD. 
Implikasi. (1) Pimpinan SKPD pada Pemerintah Kabupaten Purbalingga hendaknya dapat lebih meningkatkan partisipasi anggaran yaitu dengan cara meningkatkan keterlibatan seluruh lini pejabat struktural dalam proses penyusunan anggaran sehingga kinerja yang mereka hasilkan akan semakin baik; (2) Adanya pengaruh komitmen organisasi atas peningkatan hubungan partisipasi anggaran dengan kinerja manajerial pada Pemerintah Kabupaten Purbalingga, sangatlah perlu bagi para pejabat struktural yang terlibat dalam proses penyusunan anggaran untuk menumbuhkan komitmen organisasi yang lebih agar kinerja manajerial yang dihasilkan menjadi lebih baik lagi; (3) Walaupun dalam penelitian ini motivasi tidak dapat memoderasi namun sangat penting bagi para pejabat struktural dalam memahami faktor-faktor apa yang dapat memotivasi mereka dalam upaya peningkatan partisipasi anggaran dengan tujuan kinerja yang semakin baik. Salah satu upaya yang dapat dilakukan yaitu dengan cara menerapkan sistem reward and punishment secara nyata; (4) Struktur desentralisasi akan menempatkan para pejabat struktural sesuai tugas pokok dan fungsi, sehingga wewenang dan tanggung jawab yang menjadi tugas mereka akan membuat kinerja pejabat struktural lebih baik lagi.

\section{DAFTAR RUJUKAN}

Anthony, R.N. and V. Govindarajan. (2007) Management Control Systems. Thirteenth Edition. Boston: Mc.Graw Hill Co.

Argyris, C. (1952) The Impact of Budgets on People. Ithaca: School of Business And Administration, Cornel University.

Baihaqi. (2012) "Pengaruh Komitmen Organisasi dan Peran Manajerial Pengelolaan Keuangan Terhadap Kinerja Manajerial Satuan Kerja Perangkat Daerah”, Jurnal Fairness, 1 (3), 243-253.

Bangun, A. (2009) "Pengaruh Partisipasi dalam Penyusunan Anggaran, Kejelasan Sasaran Anggaran, dan Struktur Desentralisasi terhadap Kinerja Manajerial SKPD dengan Pengawasan Internal Sebagai Variabel Pemoderasi”, Tesis. Universitas Sumatera Utara, Medan. (Tidak Dipublikasikan).

Brownell, P. (1981) Participation in Budgeting, Locus of Control and Organizational Effectiveness, The Accounting Review. LVI (4), 844-860.

(1982a) "Participation in budgeting Process: When It Works and it Doesn't", Journal of Accounting Literature. 1, 124-153.

(1982b) "The Role of Accounting Data in Performance Evaluation, Budgetary Parcipation, and Organizational Effectivenesss”, Journal of Accounting Research, Vol.20 (Spring): 12-27.

Brownell, P. and M. Mclnnes. (1986) Budgetary Participation, Motivation and Managerial Performance, The Accounting Review, Vol.LXI October.

Chong, V.K. and K.M. Chong. (2002) Budget Goal Commitment and Informational Effect of Budget Participation on Performance A Structural Equation Modelling Approach. Behavioral Research in Accounting, Vol 114.

Coryanata, I. (2004) Pelimpahan Wewenang dan Komitmen Organisasi dalam Hubungan antara Partisipasi Penyusunan Anggaran dan Kinerja Manajerial. Simposium Nasional Akuntansi VII.

Dakli, A. (2010) "Budgetary Participation in A Non-Western Country", The Journal of Business in Developing Nations, Vol 12. 
Dunk, A.S and A.F. Lysons. (1997) “An Analysis of Departemental Effectiveness Participative Budgettaty Control Process and Environmental Dimensionality within The Competing Values Framework: A Public Sector Study”, Financial, Accountability and Manajemen, 13 (1), 1-15.

Ferdiani, D. Dan A. Rohman. (2012) "Pengaruh Partisipasi Anggaran Terhadap Kinerja Manajerial Pegawai Sekretariat Daerah Provinsi Jawa Tengah: Komitmen Organisasi Dan Persepsi Inovasi Sebagai Variabel Intervening”, Diponegoro Journal Of Accounting, 1 (1), 1-14.

Ghozali, I. (2010) Aplikasi Analisis Multivariate dengan Program SPSS. Edisi 4. Badan Penerbit Universitas Diponegoro, Semarang.

Ghozali, I dan I.M.P. Adiputra. (2002) “Pengaruh Motivasi dan Pelimpahan Wewenang Sebagai Variabel Moderating Terhadap Hubungan Antara Partisipasi Penyusuanan Anggaran Dan Kinerja Manajerial”, Journal Bisnis Strategi, VII (10), 48 - 61.

Gitosudarmo, I dan I.N. Sudita. (2009) Perilaku Keorganisasian. Yogyakarta: BPFE.

Gordon, L.A. and V.K. Narayanan. (1984) Management Accounting Systems, Perceived Enviromental Uncertainty and Organization Structure: An Empirical Investigation. Accounting, Organization and Society, 9 (4).

Govindarajan. V. (1986) "Decentralization, Strategy, and Effectivennes of Strategic Business Units in Multi- Business Organazation”, The Academy of Management Review, 11, (4), 844-856.

Gul, F.A. and Y.M. Chia. (1995) "Desentralisation as a Moderating factor in the Budgetary Partisipation Performance Relationship: Some Hongkong Evidence”, Accounting and Businnes Research, 25 (98), 107-113.

Hansen, D.R. and M.M. Mowen. (2006) Management Accounting Buku 2. Salemba Empat: Jakarta.

Hashim, A.W., I. Hanafi, A. Fitrianto and H. Darwish. (2014) Roles of Budgetary Participation on Leader's Performance: A StudyCase in Ternate. Asian Social Science, 10 (12).

Hasibuan, M. (2001) Organisasi \& Motivasi: Dasar Peningkatan Produktivitas. Bumi Aksara: Jakarta.

Herminingsih. (2009) "Pengaruh Partisipasi Dalam Penganggaran Dan Peran Manajerial Pengelola Keuangan Daerah Terhadap Kinerja Pemerintah Daerah (Studi Empiris Pada Pemerintah Kabupaten Demak)”, Tesis. Program Pasca sarjana Universitas Diponegoro, Semarang. (Tidak Dipublikasikan).

Hidayah, N dan F.E. Fauziah. (2010) "Pengaruh Partisipasi Anggaran Terhadap Kinerja Manajerial Dengan Komitmen Organisasi Sebagai Variabel Moderating”, Jurnal Dinamika Ekonomi \& Bisnis, 7 (1).

Hood, C. (1991) A Public Management For All Seasons? Public Administration, vol. 69 pp. 3-19.

Ika S., A., D. Triyani dan A. P. Lestari. (2011) Pengaruh Partisipasi Penyusunan Angggaran Terhadap Kinerja Manajerial Dengan Ketidakpastian Lingkungan, Komitmen Organisasi Dan Pelimpahan Wewenang Sebagai Variabel Moderating. Seminar Nasional Ilmu Ekonomi Terapan, Fakultas Ekonomi UNIMUS.

Indarto, S.L. dan S.D. Ayu. (2011) "Pengaruh Partisipasi Dalam Penyusunan Anggaran Terhadap Kinerja Manajerial Perusahaan Melalui Kecukupan Anggaran, Komitmen Organisasi, Komitmen Tujuan Anggaran, Dan Job Relevant Information (JRI)”, Seri Kajian Ilmiah, 14 (1). 
Jensen, M.C. and W.H. Meckling. (1976) "Theory of The Firm: Managerial Behavior, Agency Cost and Ownership Structure”, Journal of Financial Economics, 3, 305-36.

Kenis, I. (1979) Effect of Budgetary Goal Charactiristics on Managerial Attitudes and Performance. The Accounting Review, vol. LIV No.4 Oktober : 707-721.

Kren, L. (1992) Budgetary Participation and Managerial Performance: The Impact of Information and Environmental Volatility. The Accounting Review, 67 (3), 551-526.

Kristiyanti, M. (2012) "Peran Indikator Kinerja Dalam Mengukur Kinerja Manajemen”, Majalah Ilmiah InformatikaVol.3, No. 3, pp. 103-123.

KYJ, Larissa and R.J. Parker. (2008) "Antecedents of Budget Participation: Leadership Style, Information Asymmetry, and Evaluative Use of Budget”, A Journal of Accounting, Finance and Business Studies, 44 (4).

Lawler, E. E. and J.L. Suttle. (1973) Expectancy Theory and Job Behavior. Organizational Behavior and Human Performance, Ed. June pp. 482-503.

Locke, E. A. (1968) Toward a theory of task motivation and incentives. Organizational Behavior and Human Performance, pp. 157-189.

Mahoney, T.A., T.H. Jerdee and S.J. Caroll. (1963) The Jobs of Management. Industrial Relations, Ed. February, pp. 97-110.

Maiga, A.S., A. Nilsson and F.A. Jacobs. (2014) “Assesing the Impact of Budgetary Participation on Budgetary Outcomes : The Role of Information Technology for Enhanched Communication and Activity-Based Costing”, Journal Management Control. Verlag Berlin Heidelberg.

Mardiasmo. (2009) Akuntansi Sektor Publik. Penerbit Andi: Yogyakarta.

Mathieu, J. and Zajac, D. (1990) “A review of meta-analysis of the antecedents, correlates and consequences of organizational commitment”, Psychological Bulletin, 108 (2), 171-94

Meyer, J.P., N.J. Allen and C.A. Smith. (1993) “Commitment to Organisations and Occupations: Extension and test of a Three-Component Conceptualisation. Journal of Applied Psychology”, 78 (4), 538-551.

Mia, L. (1988) Managerial Attitude, Motivation and Effectiveness of Budget Participation. Accounting Organazation and Society, 13 (5), 465-475.

Milani, K. (1975) The Relationship of Participation in Budget-Setting on Industrial Supervisor Performance and Attitudes: A Field Study. The Accounting Review. Ed. April, pp.104-123.

Mowday, R.T., R.M. Steers, and L.W. Porter. (1979) "The Measurement of Organizational Commitment”. Journal of Vocational Behavior, 14, 224-247.

Nurhalimah, Darwanis dan S. Abdullah. (2013) "Pengaruh Partisipasi Penyusunan Anggaran dan Kejelasan Sasaran Anggaran terhadap Kinerja Aparatur Perangkat Daerah di Pemerintah Aceh”, Jurnal Akuntansi Pascasarjana Universitas Syiah Kuala, Aceh. 2 (1).

Noor, I.H.M. and R. Othman. (2012) Budgetary Participation: How It Affects Performance and Commitment. Accountancy Business and the Public Interest, pp. 53-73.

Nor, W. (2007) Desentralisasi dan Gaya Kepemimpinan sebagai Variabel Moderating dalam Hubungan antara Partisipasi Penyusunan Anggaran dan Kinerja Manajerial. Simposium Nasional Akuntansi X. Makassar. 
Nouri, H and R.J. Parker. (1998) The Relationship Between Budget Participation and Job Performance: The Roles of Budget Adequacy and Organizational Commitment. Accounting, Organization, and Society. Vol. 23. pp. 467-483.

Prasojo, E. (2003) Restrukturisasi Organisasi Perangkat Pemerintah Daerah:Sebuah Refleksi Teoritis dan Praxis Terhadap PP No. 8 Tahun 2003, Publikasi YIPD, Tahun II No. 3. (http://www.yipd.co.id.)

Purwati, A.S dan S. Zulaikha. (2006) "Teori Kontinjensi, Sistem Pengendalian Manajemen dan Outcomes Perusahaan: Implikasinya dalam Riset Masa Kini dan Masa Yang Akan Datang”. PERFORMANCE, Vol. 4. p. 1-11.

Porter, L.W., R.M. Steers, R.T. Mowday, and P.V. Boulian. (1974) "Organisational commitment, job satisfaction and turnover among psychiatric technicians”. Journal of Applied Psychology, vol. 59 no. 5 pp. 603-609.

Rachman, A.A. (2014) The Effect of Organization Commitment and Procedural Fairness on Participative Budgeting and Its Implication to Performance Moderating by Management Accounting Information (A Survey on Province Local Government Unit Agencies of West Java), Review of Integrative Business \& Economics Research, vol. 3 no.1.

Riyadi, S. (2000) "Motivasi dan Pelimpahan Wewenang sebagai variabel Intervening dalam Hubungan antara Partisipasi Penyusunan Anggaran dengan Kinerja Manajerial”, Jurnal Riset Akuntansi Indonesia, Ed. Juli pp. 134 - 150.

Riyanto, B. (1995) A Test of The Effect of Attitude, Strategy and Desentralization on Budget Participation: A System of Fit Approach. Makalah Simposium Nasional Akuntansi I, Yogyakarta.

(2001) "Alternative Approach to Examining A Contigency Model in Accounting Research: A Comparation”, Jurnal Riset Akuntansi, Manajemen, Ekonomi, 1 (12), 13-32.

Robbins, S.R. and T.A. Judge. (2008) Organizational Behavior. Salemba Empat: Jakarta.

Sardjito, B. dan O. Muthaher. (2007) Pengaruh Partisipasi Penyusunan Anggaran Terhadap Kinerja Aparat Pemerintah Daerah: Budaya Organisasi Dan Komitmen Organisasi Sebagai Variabel Moderating. Simposium Nasional Akuntansi $X$. Makasar.

Sekaran, U. (2003) Research Methods for Business: a Skill-building approach, $4^{\text {nd }}$ ed. John Wiley \& Sons Inc: Canada.

Shields, J.F. and M.D. Shields. (1998) Antencedents of Participate Budgeting. Accounting, Organizations and Society, 23 (1), 49-76.

Soetrisno. (2010) Pengaruh Partisipasi, Motivasi Dan Pelimpahan Wewenang Dalam Penyusunan Anggaran Terhadap Kinerja Manajerial ( Studi Empiris Pada Dinas Daerah Dan Lembaga Teknis Daerah Di Kabupaten Rembang). Tesis. Program Pasca sarjana Universitas Diponegoro, Semarang. (Tidak Dipublikasikan).

Siegel, G and H.R. Marconi. (1989) Behavioral Accounting. South Western Publishing Co. Cincinnati.

Sukmantari, D.A.M.H. dan I.W.P Wirasedana. (2015) “Pengaruh Partisipasi Penganggaran Dan Komitmen Organisasi Pada Kinerja Manajerial Dengan Kepuasan Kerja Sebagai Variabel Intervening”. E-Journal Akuntansi Universitas Udayana, Bali.

Suliyanto. (2011) Ekonometrika Terapan: Teori dan Aplikasi dengan SPSS. Yogyakarta: ANDI. 
Sutrisna, S.A. (2011)” Pengaruh Partisipasi Dalam Penyusunan Anggaran Terhadap Kinerja Manajerial Pemerintah Kota Yogyakarta Dengan Pendekatan Kontigensi”, ASSETS Vol. 1 No. 2.

Suhartono, E. dan A. Halim. (2005) "Pengaruh partisipasi penyusunan anggaran dan kejelasan sasaran anggaran terhadap kinerja manajerial pemerintah daerah dengan motivasi sebagai variabel pemoderasi: Studi empiris pada kota dan kabupaten sePropinsi Daerah Istimewa Yogyakarta”, E-Journal FEB UGM. Yogyakarta.

Syahputra, Z. (2014) "Budget Participation on Managerial Performance: Related Factors in that influenced to Government's Employee (Study of Indonesian Local Government)”, Journal of Economics and Sustainable Development, Vol. 5 No. 21. 